\title{
Use of chemosynthetic biomass by large, mobile, benthic predators in the Gulf of Mexico
}

\author{
Stephen E. MacAvoy ${ }^{1, *}$, Robert S. Carney ${ }^{2}$, Charles R. Fisher ${ }^{3}$, Stephen A. Macko ${ }^{1}$ \\ ${ }^{1}$ Department of Environmental Sciences, University of Virginia, Charlottesville, Virginia 22903, USA \\ ${ }^{2}$ Coastal Ecology Institute, Louisiana State University, Baton Rouge, Louisiana 70803, USA \\ ${ }^{3}$ Biology Department, Pennsylvania State University, University Park, Pennsylvania 16802, USA
}

\begin{abstract}
The Gulf of Mexico supports communities of chemoautotrophic and heterotrophic fauna associated with hydrocarbon seeps. The chemoautotrophic invertebrates, mostly dense epifaunal assemblages of mussels and tubeworms, derive their nutrition from symbiotic relationships with sulfide- or methane-oxidizing bacteria. The extent to which benthic predatory fauna feed on the chemoautotrophic assemblages has been an open question. Owing to differences in stable isotope values between chemosynthetic- and photosynthetic-derived biomass, isotopic characterization of predatory fauna would be useful in determining their dependence upon chemoautotrophs for food. Carbon and sulfur stable isotope analyses reveal that fishes with similar feeding strategies (rat tail [Nezumia sp.] and eels [Synaphobranchus sp., Ophicthus cruentifer and Dysomma rugosa]) have similar $\delta^{13} \mathrm{C}$ values $(-32.7$ and $-42.5 \%$, respectively), reflecting chemoautotrophic carbon. Large vagrant predators/scavengers such as isopods Bathynomus giganteus, hagfish Eptatretus sp. and spider crabs Rochina crassa, have isotope values closer to oceanic ranges $\left(\delta^{13} \mathrm{C}:-20\right.$ to $-18 \% ; \delta^{34} \mathrm{~S}: 18$ to $20 \%$ ), although some individual Eptatretus sp. and $R$. crassa show a chemosynthetic component. Colonist invertebrates, such as the sea star (Sclerasterias cf. tanneri) and a predatory snail Buccinum canetae, have greatly depleted $\delta^{13} \mathrm{C}$ and $\delta^{34} \mathrm{~S}$ values, indicating an almost $100 \%$ reliance on seep production. Nitrogen isotope ratios are depleted $(-19 \%)$ in some seep areas, and B. canetae and Synaphobranchus sp. reflect the ${ }^{15} \mathrm{~N}$ depletion (-10 and $-3 \%$ respectively). On a species-specific basis, some mobile benthic predators from the background fauna obtain close to $100 \%$ of their nutrition from seep production, indicating that they are residents of the seeps. There is a high degree of movement in and out of the seep habitat by vagrant benthic predators, and although the majority derive most of their nutritional needs from photosynthetic production, the incorporation of chemosynthetic production is substantial.
\end{abstract}

KEY WORDS: Chemosynthetic production $\cdot$ Benthic marine predators $\cdot$ Stable isotopes

\section{INTRODUCTION}

The hydrocarbon seep communities of the deep Gulf of Mexico are fundamentally similar to those of other deep chemosynthetic systems, supporting dense assemblages of chemoautotrophic-based tube worms and mussels occupied by a more diverse group of heterotrophic species (Kennicutt et al. 1985, Brooks et

*Present address: Biology Department, 101 Hurst Hall, American University, 4400 Massachusetts Ave. NW, Washington, DC 20016, USA. E-mail: macavoy@american.edu al. 1987). These very high standing-stock communities are surrounded by a low standing-stock background community of typical deep-sea species with a phytoplankton detritus-based food web. A fundamental question addressed herein arises from the dramatic contrast in apparent productivity of the 2 communities: to what extent do the background species exploit the chemosynthetic production? Indeed, the paucity of food in the deep environment is thought to be so pronounced and persistent that there is extreme competition for food on both ecological and evolutionary time scales (Jumars et al. 1990, Gage \& Tyler 1996). Upon 
initial consideration, a high degree of predation by the background fauna would be expected.

Two possible types of exploitation by background species have already been established from the species composition of hydrothermal vents and cold seeps:

(1) feeding by a resident community of consumers, and

(2) feeding by vagrant species (Tunnicliffe \& Jensen 1987, Tunnicliffe 1992). Resident species would be expected to be part of a relatively closed food web, foraging as resident populations only within a seep or vent community. Vagrant species would bridge the chemosynthetic system and the background, forming no resident populations within seep or vent sites, but foraging across their extensive photosyntheticallybased background range with forays into the chemosynthetic systems. Owing to the relatively well-established taxonomic database for the deep Gulf of Mexico, it has been possible to distinguish background species from seep residents. In addition to populations of true seep endemic species, the resident consumer community contains species which have colonized from the background. Such colonists are typically rare in the background, and appear to have elevated population densities within the seep sites (Carney 1994). It was the purpose of this study to establish the degree of seep primary-production utilization by both types of mobile predators and to gain a better understanding of trophic export by the vagrant consumer route.

The results of a prior isotopic survey of deep Gulf of Mexico benthos gave initial evidence that trophic export due to vagrant consumption may be substantial (Kennicutt unpubli data). That study, initiated prior to the discovery of the seeps, collected fauna with a $9 \mathrm{~m}$ semi-balloon otter trawl along 4 transects spanning 320 to $2953 \mathrm{~m}$ depth and lying between $27^{\circ} 35.0^{\prime} \mathrm{N}$, $93^{\circ} 33.1^{\prime} \mathrm{W} ; 6^{\circ} 17.2^{\prime} \mathrm{N}, 93^{\circ} 19.2^{\prime} \mathrm{W} ; 28^{\circ} 27.2^{\prime} \mathrm{N}, 86^{\circ} 01.0^{\prime} \mathrm{W}$; and $28^{\circ} 04.4^{\prime} \mathrm{N}, 86^{\circ} 34.8^{\prime} \mathrm{W}$ (Pequegnat et al. 1990). The slope megafauna (132 specimens of 42 species) showed a well-defined $\delta^{13} \mathrm{C}$ distribution centered at $-17.8 \pm 1.2 \%$ consistent with a photosynthetic plankton food source, along with an indication of a second cluster of 22 values centered at a more depleted $-20.8 \%$. Interpretation of the lower values as being due to some dependence on a chemosynthetic food source was strengthened by the identity of the species collected (seep chemosynthetic production may be ${ }^{13} \mathrm{C}$-depleted relative to photosynthetic production, see below). Of the five $\delta^{13} \mathrm{C}$-depleted species, 3 are now known to be seep vagrants - the large mobile crab Chaceon (Geryon) quinquedens, the eel Synaphobranchus sp., and the hake Urophysis cirratus. Since none of the trawl samples contained seep endemics, it appears that the $17 \%$ of the total catch that had indications of seep-derived carbon could be the result of trophic export into the background. The lack of multi- ple isotope tracers and of information as to seep proximity, however, makes such a conclusion tenuous (for a review of stable isotopic analysis and ecological studies see Lajtha \& Michener 1994).

The Gulf of Mexico hydrocarbon seep communities have been observed and sampled for more than $10 \mathrm{yr}$, resulting in substantial on-site information on species composition, classification of endemics, colonists, and vagrants, and food-web ecology (MacDonald et al. 1989, Carney 1994, Fisher 1996, Kennicutt unpubl. data). The biotic substrate of the communities is formed by various combinations of abundant tube worms and bivalves that harbor chemosynthetic symbiotic bacteria. Two tube worm species, a Lamellibranchia species and an Escarpia-like species, as well as the comparatively rare mussel Tamu fisheri and the peripheral lucinid and vesicomyid clams are all symbiotic with sulfur-oxidizing chemoautotrophic bacteria (Brooks et al. 1987, Fisher et al. 1993). The mussel Bathymodiolus childressi is the most abundant bivalve at the seeps and it is symbiotic with methanotrophic bacteria (Childress et al. 1986). Closely associated with the tube worm bushes and mussel beds are at least 2 dozen heterotrophic species, dominated by endemic grazing gastropods, smaller decapod crustaceans, and worms of several phyla. Mussel beds usually lack sessile epizoa but, poriferans and hydroids are common on tube worm tubes (Maldonado \& Young 1988, Carney 1994). For mussel beds the predominant colonists are both predators - the gastropod Buccinum canetae and the sea star Sclerasterias cf. tanneri. On-site, larger more motile predatory animals classified as vagrants include the hagfish Eptatretus, the large spider crab Rochina crassa, the eels Synaphobranchus, Ophicthus cruentifer and Dysomma rugosa, the rat-tail fish Nezumia sp., and the giant isopod Bathynomus giganteus.

The most useful tool for determining the past consumption of any animal sampled on- or off-site is stable isotope analysis. The value of such tracers for determining the nutrient source utilization by and trophic interactions among consumers has been well established in many terrestrial and aquatic systems (for review see Fry \& Sherr 1984, Michener \& Schell 1994). Consumers reflect the $\delta^{13} \mathrm{C}$ of their food source (which can differ depending on the process of $\mathrm{CO}_{2}$ fixation and $\left.\left[\mathrm{CO}_{2}\right]\right)$ plus approximately $1 \%$ accounting for the trophic fractionation (Fry \& Sherr 1984). Therefore, in systems where isotopically distinct nutrient sources are available the relative importance of sources to consumer species can be determined. Trophic level can be determined among consumer species with $\delta^{13} \mathrm{C}$ because of the $1 \%$ enrichment relative to their diet. Nitrogen isotopes can also be used to differentiate nutrient sources and provide an even more definitive 
indication of trophic level. Marine and estuarine phytoplankton and their consumers are enriched by several \%o relative to terrestrial autotrophs. Additionally, there is a 3 to $3.5 \%$ enrichment in $\delta^{15} \mathrm{~N}$ per trophic level (Michener \& Schell 1994 and references therein). Therefore, both carbon and nitrogen isotopes combined can provide nutrient source and trophic information. Sulfur isotopes are also proving useful as nutrient tracers in systems where marine and freshwater nutrients mix (Peterson \& Howarth 1987, Hesslein et al. 1991, MacAvoy et al. 1998). Ocean phytoplankton have a fairly uniform $\delta^{34} \mathrm{~S}$ value of about 18.5 to $19 \%$ (Peterson \& Howarth 1987). Terrestrial autotrophs are depleted relative to phytoplankton, and the isotopic composition of $\mathrm{H}_{2} \mathrm{~S}$ in reducing sediments can reach values of $-20 \%$ or lower (Michener \& Schell 1994). Additionally, $\delta^{34} \mathrm{~S}$ is thought to undergo minimal or no fractionation as a function of trophic level, making it an excellent tracer for nutrients since no correction due to trophic fractionation is needed.

There is a special utility for stable isotope analysis in deep-sea chemoautotrophic systems owing to the distinctiveness of the produced biomass. It was the fact that vent tube worms had very distinct $\delta^{13} \mathrm{C}$ values relative to typical deep-ocean tissue carbon values, that led Rau \& Hedges (1979) to postulate that the dominant invertebrates had some non-photosynthetic food source. In hydrocarbon seep communities, $\delta^{13} \mathrm{C}$ has been the primary isotope value examined. It has been used to help differentiate animals with chemoautotrophic symbionts ( -20 to $-40 \%$ ) from those with methanotrophic symbionts $(\leq-40 \%$ ) (Brooks et al. 1987, Kennicutt et al. 1992) and to identify the source methane pool as either thermogenic $\left(\delta^{13} \mathrm{C}=-40\right.$ to $-45 \%$ ) or biogenic $\left(\delta^{13} \mathrm{C} \leq-45 \%\right.$ ) methane (Sassen et al. 1999). Some $\delta^{15} \mathrm{~N}$ and $\delta^{34} \mathrm{~S}$ measurements have also been made on seep chemoautotrophs and heterotrophs (Brooks et al. 1987). Chemoautotrophs tended to have lower $\delta^{15} \mathrm{~N}$ values ( -5 to $-12 \%$ ) than heterotrophs (2.8 to $13 \%$ ) or marine phytoplankton. The $\delta^{34} \mathrm{~S}$ values of the thiotrophic animals were depleted relative to the methanotrophic bivalves (13\%) and seep heterotrophs (13 to 16\%) (Brooks et al. 1987). Because of the large and significant differences in isotope signature between photosynthetically derived biomass in the ocean and chemosynthetically derived biomass at the seep, examination of the isotopic ratios of predators in and around the seep should reveal their degree of utilization of seep primary production.

\section{MATERIAL AND METHODS}

On- and off-site sampling of fauna was carried out on 1997 and 1998 cruises of the RV 'Edwin Link' and the
'Johnson Sea Link' submersible in the Green Canyon Lease Area region of the Gulf of Mexico. This is a $22000 \mathrm{~km}^{2}$ region of seafloor under US economic control lying between the 200 and $2400 \mathrm{~m}$ isobaths on the topographically and geochemically complex continental slope off the coast of Louisiana. For the management of oil and gas development the area is subdivided into $4.8 \times 4.8 \mathrm{~km}$ numbered lease blocks (Fig. 1). The sites sampled for this study were in lease blocks Green Canyon 185: GC 185, 'Bush Hill'; GC 233: 'Brine Pool'; and GC 234. These sites are active hydrocarbon seep areas with chemoautotrophic fauna that have been studied for various purposes for more than a decade.

The GC 185 (Bush Hill) site $\left(27^{\circ} 46.96^{\prime}\right.$ N, 91 $\left.{ }^{\circ} 30.46^{\prime} \mathrm{W}\right)$ is at a depth of 540 to $580 \mathrm{~m}$. The dominant fauna at the site are tube worms, although mussel beds are found throughout the site as well. Methane and oil are actively seeping from the sediments and carbonate outcrops are scattered over the site (Nix et al. 1995). The GC 234 site $\left(27^{\circ} 44.7^{\prime} \mathrm{N}, 91^{\circ} 13.3^{\prime} \mathrm{W}\right)$ is at a depth of approximately $540 \mathrm{~m}$. Similar to GC 185, fauna at this site is dominated by tube worms with abundant mussel beds. Methane gas and oil has been observed leaking from sediments (Nix et al. 1995). The GC 233 site $\left(27^{\circ} 43.4^{\prime} \mathrm{N}, 91^{\circ} 16.8^{\prime} \mathrm{W}\right)$ is at a depth of $640 \mathrm{~m}$. It is dominated by an anoxic brine pool that arises from saline seepage along a fault (Reilly et al. 1996, Sassen et al. 1999). Biogenic methane-utilizing Bathymodiolus childressi mussels are the dominant fauna at the site, tube worms are scarce (MacDonald et al. 1990, Smith et al. 2001).

On-site collection of mobile predatory fauna was carried out with small (approx. $3 \times 4 \times 2 \mathrm{ft}$ : $0.91 \times 1.22$ $\times 0.61 \mathrm{~m}$ ) wire-mesh traps deployed within and around tube worm and mussel beds at GC 234 and GC 233. Trap collections were augmented by direct capture by the submersible via a suction sampler and bushmaster collection nets (Urcuyo et al. 2001). Off-site mobile predators were caught with surface-deployed Z-frame traps, $5 \times 6 \times 3 \mathrm{ft}(1.52 \times 1.83 \times 0.91 \mathrm{~m})$, set approximately $2 \mathrm{~km}$ off the location of the seep communities in areas known from prior surveys to lack active seep communities. Both small and Z-traps were intended to capture the same types of animals. They both were constructed of 1 inch $(2.54 \mathrm{~cm})$ square trap mesh, equipped with two $20 \mathrm{~cm}$ entry mouths, and baited with menhaden Brevoortia tyrannus in a wire bait cage to minimize consumption. Trap soak time (duration of deployment) was determined by cruise logistics, ranging from 1 to $6 \mathrm{~d}$.

Samples of muscle tissue were taken from captured organisms and kept frozen until shipment to the University of Virginia for analysis. Isotopic determinations were made on samples dried at $60^{\circ} \mathrm{C}$ for $3 \mathrm{~d}$ and homogenized. Approximately 5 to $6 \mathrm{mg}$ of tissue was 


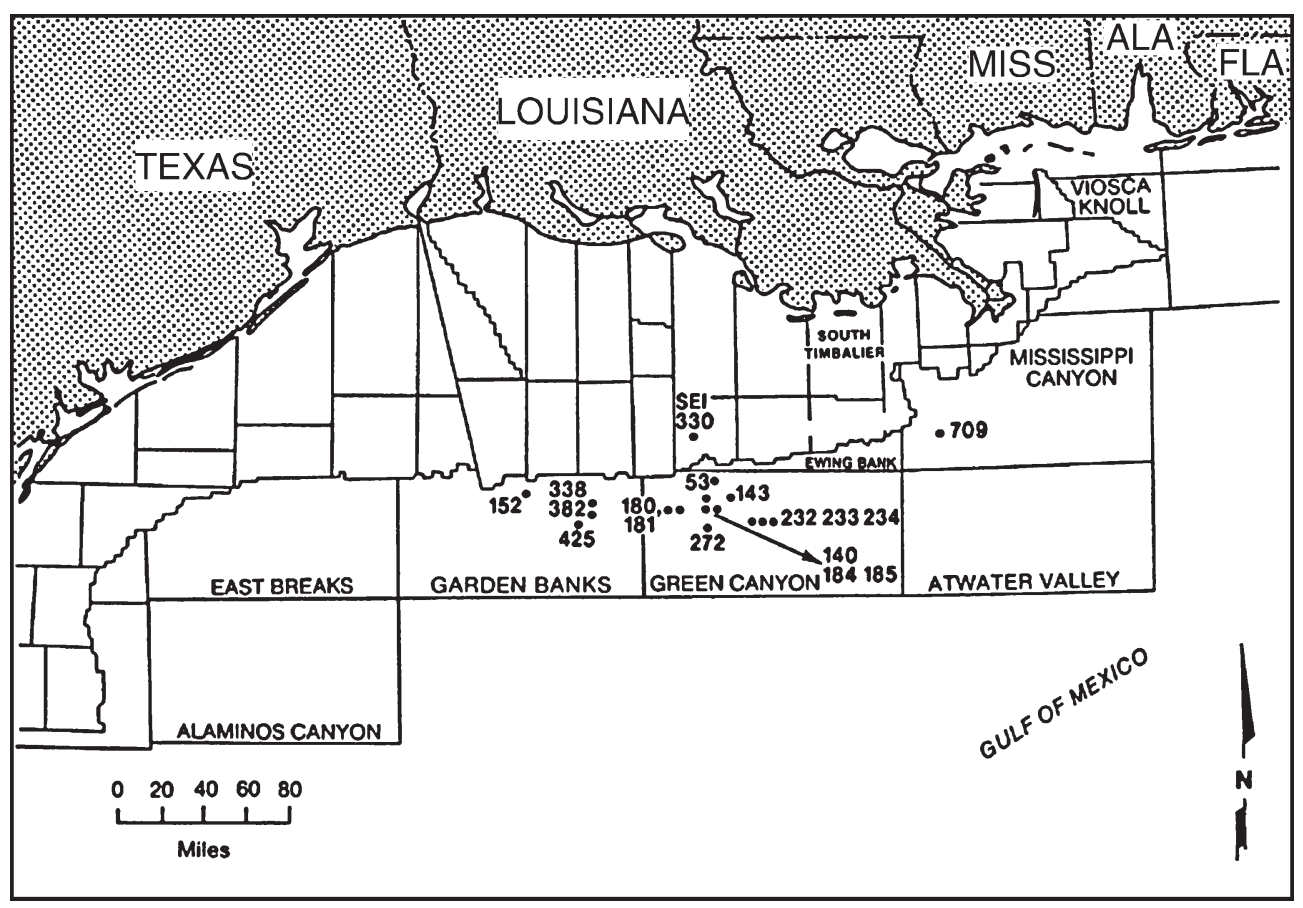

Fig. 1. Locations of the Green Canyon (GC) and Garden Banks lease areas. Chemosynthetic communities and their associated predators at GC 185, GC 233 and GC 234 were the focus of this study (adapted from Roberts \& Carney 1997) used for $\delta^{34} \mathrm{~S}$ measurements and 0.6 to $1.0 \mathrm{mg}$ was used for $\delta^{13} \mathrm{C}$ and $\delta^{15} \mathrm{~N}$ measurements. Computation of the delta value follows the same procedure for all stable isotopic measurements, as follows:

$$
\left.\delta^{x} E=\left[\left({ }^{x} E /{ }^{y} E\right)_{\text {sample }} /\left({ }^{x} E /{ }^{y} E\right)_{\text {standard }}\right]-1\right) \times 1000
$$

where $E$ is the element analyzed (C, N or S), $x$ is the atomic weight of the heavier isotope, and $y$ is the atomic weight of the lighter isotope $(x=13,15,34$ and $y=12,14,32$ for $\mathrm{C}, \mathrm{N}$ and $\mathrm{S}$ respectively). The standard materials to which the samples were compared were PDB (Pee Dee Belemnite) for carbon, air $\mathrm{N}_{2}$ for nitrogen and CDT (Canyon Diablo Triolite) for sulfur. A Carlo Erba elemental analyzer coupled to a VG Optima isotope ratio mass spectrometer (Micromass ${ }^{\circledR}$, Manchester, UK) was used for all isotopic measurements (EA/IRMS: Fry et al. 1992, Giesemann et al. 1994). Reproducibility of all measurements was typically $0.3 \%$ or better.

Since vagrant species are expected to have a diet combining seep production with phytodetritus organisms, analyses included assessment of food-source mixing. Isotopic mixing equations can be used to quantify food source dependence in systems with isotopically distinct food sources. The general form of the mixing equation used is:

$\delta^{x} E_{\text {predator }}-F=\left(\delta^{x} E_{\text {seep }} \times f_{\text {seep }}\right)+\left(\delta^{x} E_{\text {ocean }} \times\left(1-f_{\text {seep }}\right)\right)$

where $f_{\text {seep }}$ is the fraction of diet from chemosynthetic sources and $\delta^{x} E_{\text {seep }}$ and $\delta^{x} E_{\text {ocean }}$ are the mean isotopic signatures of the chemosynthetic material and background ocean respectively. The parameter $F$ corrects for trophic enrichment and is dependent on the isotope used.

The values used for the mean isotopic signatures of the chemosynthetic prey, $\delta^{x} E_{\text {seep }}$, were calculated siteby-site, averaging values for selected resident fauna exclusive of vagrant species. The phytodetritus-based food sources of the background were considered to be relatively homogenous, and a single set of $\mathrm{C}, \mathrm{N}$ and $\mathrm{S}$ isotope values determined from the literature were used in Eq. (2). The $\delta^{13} \mathrm{C}_{\text {ocean }}$ value of $-17 \%$ was used as being typical of values between phytoplankton and background predators (Fry \& Sherr 1984, Peterson \& Howarth 1987, Michner \& Schell 1994, Roelke \& Cifuentes 1997). The $\delta^{15} \mathrm{~N}_{\text {ocean }}$ value of $10 \%$ was used (Fry 1983, Macko et al. 1984). The $\delta^{34} \mathrm{~S}_{\text {ocean }}$ value of $18.5 \%$ was used (Peterson \& Howarth 1987, MacAvoy et al. 1998). When using $\delta^{13} \mathrm{C}$ and $\delta^{15} \mathrm{~N}, \mathrm{~F}$ was given a value of 1 and $3 \%$ respectively, which is the trophic enrichment typically associated with these isotopes. Sulfur isotopes do not significantly fractionate with trophic transfer (Michener \& Schell 1994), therefore $F=0$ when using $\delta^{34} \mathrm{~S}$.

Nonparametric methods were used for all comparisons. Mann-Whitney $U$-tests were used for 2 group comparisons and Kruskal-Wallis tests were used for multiple comparisons. The Dunn procedure was used to compare specific differences among groups once Kruskal-Wallis indicated significant differences (Ros- 
ner 1990, Lee 1992). Microsoft Excel 5.0 (Microsoft, Inc., Seattle) and Statview $\mathrm{SE}+$ Graphics (Abacus Concepts, Inc., Berkeley, CA) were used for individual statistical tests.

\section{RESULTS}

On-site small and off-site Z-traps proved an effective means of collecting 3 vagrant species, the spider crab Rochina crassa, the giant isopod Bathynomus giganteus, and the hagfish Eptatretus sp. R. crassa is a true crab reported from 400 to $800 \mathrm{~m}$ deep on the upper slope from New England to the Gulf of Mexico (Pequegnat 1970). Eptatretus sp., a hagfish, is a cosmopolitan jawless fish found at all depths in the Gulf of Mexico. Although the thin hagfish could easily escape through the trap mesh, they sometimes entered the smaller bait cage and were retained during retrieval. B. giganteus is the largest living isopod, reaching a body size of $48 \mathrm{~cm}$ in our collections, and is an example of occasional evolutionary gigantism in deep-sea pericardid crustaceans attributed to niche-filling in the comparative absence of large predatory crabs and fishes (Gage \& Tyler 1996). The species appears to be restricted to the Gulf of Mexico, Caribbean, and adjacent Atlantic slope, but the genus is cosmopolitan. The capture of other animals by the traps was quite limited, possibly due to voracious feeding in the trap by the giant isopods.

\section{Site GC 234}

Site-specific values for the isotopic signatures of the seep food sources was developed from a selection of 3 symbiont-hosting and 5 resident heterotrophs (Table 1). The values obtained were $-32.1 \pm 8.3 \% \delta^{13} \mathrm{C}(\mathrm{n}=11), 6.1 \pm 3.2 \%{ }^{15} \mathrm{~N}$ $(\mathrm{n}=11)$, and $4.8 \pm 2.8 \% \delta^{34} \mathrm{~S}(\mathrm{n}=3)$. The mean chemosynthetic $\delta^{13} \mathrm{C}$ value of prey items at GC 234 was statistically indistinguishable from that at GC 185 and virtually identical when tube worms were excluded. For this reason, 1 value for $\delta^{13} C_{\text {seep }}(-32 \pm 6 \%)$ was
Table 1. Stable isotope values for prey fauna from the 3 study sites. The mean and standard deviation of these values were used in isotope mixing equations to determine the exploitation of chemosynthetic production by large, heterotrophic fauna captured both on- and off-site

\begin{tabular}{|c|c|c|c|}
\hline Species & $\delta^{13} \mathrm{C}$ & $\delta^{15} \mathrm{~N}$ & $\delta^{34} \mathrm{~S}$ \\
\hline \multicolumn{4}{|l|}{ GC 185} \\
\hline Phascoloma turnerae (sipunculid) & -27.9 & 6.0 & -12.3 \\
\hline Phascoloma turnerae (sipunculid) & -32.5 & 8.9 & 2.2 \\
\hline Neretid polycheate & -29.9 & 5.4 & -9.3 \\
\hline Munidopsis Type 1 (squat lobster) & -28.9 & 7.7 & \\
\hline Munidopsis Type 1 (squat lobster) & -7.5 & & \\
\hline Munidopsis Type 1 (squat lobster) & -32.0 & 6.8 & -2.1 \\
\hline Munidopsis Type 1 (squat lobster) & -30.1 & 6.9 & -13.0 \\
\hline Munidopsis Type 1 (squat lobster) & -30.9 & 6.5 & -4.4 \\
\hline Nemertian worm & -23.1 & 7.5 & -6.1 \\
\hline Alvinocaris stactophila (shrimp) & -31.3 & 6.7 & 1.5 \\
\hline Escarpia-like species (tube worm) & -21.9 & 3.7 & -33.7 \\
\hline Bathynertia naticoidea (snail) & -29.6 & 7.0 & -3.4 \\
\hline Bathynertia naticoidea (snail) & -29.6 & 7.0 & -3.4 \\
\hline Bathynertia naticoidea (snail) & -30.9 & 5.8 & -7.7 \\
\hline $\begin{array}{l}\text { Harmathoe sp. } \\
\text { (red head polynoid worm) }\end{array}$ & -23.7 & 7.0 & -12.6 \\
\hline $\begin{array}{l}\text { Eurythoe sp. } \\
\text { (hairy polychaete worm) }\end{array}$ & -40.6 & 8.1 & -12.0 \\
\hline Bathymodiolus childressi (mussel) & -43.0 & 7.8 & -4.1 \\
\hline Bathymodiolus childressi (mussel) & -40.6 & 8.3 & -1.3 \\
\hline Bathymodiolus childressi (mussel) & -41.3 & 1.5 & 2.3 \\
\hline Mean $\pm \mathrm{SD}$ & $-31.2 \pm 6.0$ & $6.9 \pm 1.2$ & $-7.3 \pm 8.4$ \\
\hline \multicolumn{4}{|l|}{ GC 234} \\
\hline Phascoloma turnerae (sipunculid) & -30.3 & 7.8 & 1.5 \\
\hline Alvinocaris stactophila (shrimp) & -24.1 & 7.6 & \\
\hline Munidopsis Type 2 (squat lobster) & -27.4 & 9.6 & 6.1 \\
\hline Escarpia-like species (tube worm) & -27.5 & 5.9 & \\
\hline Lamellibranchia sp. (tube worm) & -25.3 & 4.6 & \\
\hline Alvinocaris stactophila (shrimp) & -28.9 & 10.1 & \\
\hline Polychaete \#2 (worm) & -29.8 & 10.6 & \\
\hline Bathymodiolus childressi (mussel) & -36.9 & 5.4 & \\
\hline Bathymodiolus childressi (mussel) & -45.5 & 2.5 & 6.7 \\
\hline Bathymodiolus childressi (mussel) & -44.0 & 1.8 & \\
\hline Bathymodiolus childressi (mussel) & -43.1 & 3.0 & \\
\hline Mean $\pm \mathrm{SD}$ & $-32.1 \pm 8.3$ & $6.1 \pm 3.2$ & $4.8 \pm 2.8$ \\
\hline \multicolumn{4}{|l|}{ GC 233} \\
\hline Bathynerta naticoidea (snail) & -51.6 & -6.5 & 6.6 \\
\hline Bathynerta naticoidea (snail) & -52.4 & -5.6 & 11.2 \\
\hline Bathymodiolus childressi (mussel) & -69.0 & -20.9 & 11.6 \\
\hline Bathymodiolus childressi (mussel) & -65.0 & -17.9 & 14.6 \\
\hline Bathymodiolus childressi (mussel) & -61.8 & -16.8 & \\
\hline Orbinid sp. (worm) & -60.0 & -9.3 & 15.9 \\
\hline Alvinocaris stactophila (shrimp) & -36.5 & -4.4 & \\
\hline Cycloporus sp. (flat worm) & -61.3 & -16.4 & 15.9 \\
\hline Cycloporus sp. (flat worm) & -58.9 & -14.6 & 17.2 \\
\hline Mean $\pm \mathrm{SD}$ & $-57.3 \pm 9.6$ & $-12.5 \pm 6.1$ & $13.3 \pm 3.7$ \\
\hline
\end{tabular}

used in mixing equations for both GC 234 and GC 185 (see following subsections).

Two species of vagrant predators were captured in the small on-site trap at GC 234, Bathynomus giganteus (2 specimens), and Eptatretus sp. (11 specimens), along with a single specimen of the predatory gastro- 
pod Buccinum canetae (Fig. 2). Three species of fishes were directly captured (as opposed to trap captured) as part of tube worm aggregation collections at the GC 234 site: the eel, Synaphobranchus, the brotulid Oligopus sp., and a viperfish Chauliodis sloani.

The on-site Bathynomus giganteus and Eptatretus yielded values reflective of heavy reliance on photosynthetically-derived foods rather than the surrounding chemoautotrophic production, but showed speciesspecific differences. The 2 specimens of $B$. giganteus were significantly more enriched in ${ }^{13} \mathrm{C}$ and ${ }^{15} \mathrm{~N}$ ( $p=0.05$ and 0.03 respectively) than the Eptatretus and were isotopically similar to 'typical' ocean fauna (Table 2). The relatively large sample size for Eptatretus did, however, reveal a pattern for $\delta^{13} \mathrm{C}$ and $\delta^{34} \mathrm{~S}$ consistent with limited consumption of chemoautotrophic tissue. The ranges of $\delta^{13} \mathrm{C}, \delta^{15} \mathrm{~N}$ and $\delta^{34} \mathrm{~S}$ values for captured Eptatretus were -18.3 to $-16.3 \%$, 7.3 to $12.2 \%$ and 12.1 to $18.5 \%$ respectively with a trend toward depletion in ${ }^{13} \mathrm{C}$ and ${ }^{34} \mathrm{~S}$ (Fig. 2). Several of the Eptatretus had $\delta^{34} \mathrm{~S}$ values that were quite depleted relative to ocean sulfate, and a simple regression of $\delta^{13} \mathrm{C}$ with $\delta^{34} \mathrm{~S}$ was significant $(\mathrm{p}=0.02)$.

Supportive evidence that the Eptatretus population consumes some seep production was found in the calculation of the mixing equation based on $\delta^{34} \mathrm{~S}$. It is estimated that the on-site Eptatretus population caught at GC 234 derived, on average, between 7 and $12 \%$ of their dietary sulfur from chemosynthetic sources (Table 2). The standard deviations associated with the mixing equations were, however, large and equal to the mean. The median percent of dietary sulfur that originated from chemosynthetic sources was between 3 and $6 \%$, depending on the $\delta^{34} S_{\text {seep }}$ value used.

The seep-resident gastropod and fishes showed markedly different trophic dependency from the trapped vagrants. The gastropod Buccinum canetae, and the fishes Synaphobranchus and Oligopus sp. displayed $\delta^{13} \mathrm{C}, \delta^{15} \mathrm{~N}$ and $\delta^{34} \mathrm{~S}$ values consistent with a diet of predominately chemoautotrophic tissue. Solution of the mixing equation for $\delta^{13} \mathrm{C}$ showed that all 3 species consumed between 50 and $100 \%$ seep-produced carbon. The tissue $\delta^{15} \mathrm{~N}$ values of the fishes placed them near the top of the seep-colonist food chain (Table 2). The tissue stable isotope values of the viperfish Chauliodis sloani indicated moderate levels of consumption of seep fauna (10 to $24 \%$ ).

Three species of vagrant predators were caught offsite at Z-traps approximately $2 \mathrm{~km}$ from a known seep community at GC $234\left(27^{\circ} 45.9^{\prime} \mathrm{N}, 91^{\circ} 11.6^{\prime} \mathrm{W}\right)$. In addition to Rochina crassa (3 specimens) and Bathynomus giganteus (5 specimens), 1 hake Urophysis sp. was captured (Fig. 3). All individuals had isotope values similar to those seen in other pelagic Gulf of

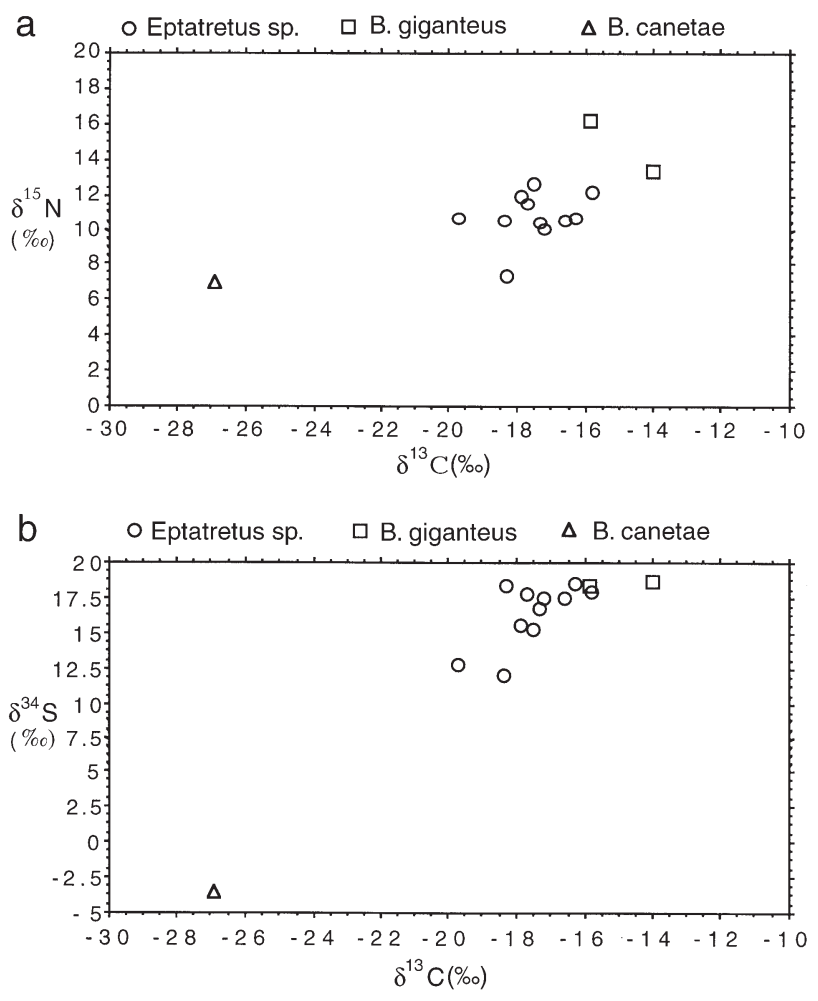

Fig. 2. (a) $\delta^{13} \mathrm{C}$ vs $\delta^{15} \mathrm{~N}$ and (b) $\delta^{13} \mathrm{C}$ vs $\delta^{34} \mathrm{~S}$ for animals collected from small traps depoloyed at GC 234. Eptatretus sp. is a hagfish, Bathynomus giganteus a giant isopod, and Buccinum canetae a predatory snail

Mexico predators. B. giganteus on-site were more enriched in ${ }^{13} \mathrm{C}$ and ${ }^{15} \mathrm{~N}$ than those captured off-site, although not significantly so $(p=0.08)$. Off-site, there was no statistical difference between the $\delta^{34} \mathrm{~S}$ of $R$. crassa and B. giganteus. As a group, the predators collected off-site in the Z-trap were significantly more enriched in $\delta^{34} \mathrm{~S}$ than those caught in the small on-site trap $(p=0.0002)$. It is unlikely that these off-site vagrants consumed any appreciable amount of chemosynthetically derived material.

\section{Site GC 185}

A site-specific value for the isotopic signature of the seep food sources was developed from a selection of 2 symbiont-hosting and 8 resident heterotrophs (Table 1). The values obtained were $-31.2 \pm 6.0 \% \quad \delta^{13} \mathrm{C}_{\text {seep }}$ $(\mathrm{n}=18), 6.9 \pm 1.2 \% \delta^{15} \mathrm{~N}(\mathrm{n}=18)$, and $-7.3 \pm 8.4 \%$ o $\delta^{34} \mathrm{~S}$ $(\mathrm{n}=18)$. As noted in the previous section, the mean chemosynthetic $\delta^{13} \mathrm{C}$ value of prey items at GC 185 was statistically indistinguishable from that at GC 234 and therefore an intermediate value of $\delta^{13} \mathrm{C}_{\text {seep }}$ of $-32 \pm$ $6.0 \%$ was used for both sites. 
Table 2. Means \pm SP and (N) isotope values for animals captured on- and off-site at GC 234, GC 233 and GC $185 . \%$ of chemosynthetic material: estimate of biomass carbon or sulfur derived from chemosynthetic production (carbon isotopes were used to calculate this percentage unless noted otherwise

\begin{tabular}{|c|c|c|c|c|}
\hline Species & $\delta^{13} \mathrm{C}$ & $\delta^{15} \mathrm{~N}$ & $\delta^{34} \mathrm{~S}$ & $\begin{array}{c}\% \text { chemosynthetic } \\
\text { material }\end{array}$ \\
\hline \multicolumn{5}{|l|}{ GC234, on-site } \\
\hline \multicolumn{5}{|l|}{ Vertebrates } \\
\hline Eptatretus sp. & $-17.5 \pm 1.1(11)$ & $10.8 \pm 1.4(11)$ & $16.2 \pm 2.2(12)$ & $7-12$ \\
\hline Oligopus sp. ${ }^{\mathrm{a}}$ & $-27.3 \pm 0.3(2)$ & $9.9 \pm 0.3(2)$ & & $53-100$ \\
\hline Synaphobranchus sp. ${ }^{a}$ & -24.9 & 8.5 & & $42-100$ \\
\hline Chauliodis slonani ${ }^{\mathrm{a}}$ & -18.2 & 10.7 & & $10-24$ \\
\hline \multicolumn{5}{|l|}{ Invertebrates } \\
\hline Bathynomous giganteus & $-14.9 \pm 1.3(2)$ & $14.8 \pm 2.0(2)$ & $18.5 \pm 3.0(2)$ & 0 \\
\hline Buccinum canetae & $-26.9(1)$ & $7.0(1)$ & $-3.5(1)$ & $50-100$ \\
\hline \multicolumn{5}{|l|}{ GC234, off-site Z-traps } \\
\hline \multicolumn{5}{|l|}{ Vertebrates } \\
\hline Urophysis sp. & $-17.5(1)$ & $12.3(1)$ & $20.0(1)$ & 0 \\
\hline \multicolumn{5}{|l|}{ Invertebrates } \\
\hline Bathynomous giganteus & $-15.7 \pm 0.3(2)$ & $14.5 \pm 0.2(2)$ & $20.5 \pm 0.7(5)$ & 0 \\
\hline Rochina crassa & $-17.9 \pm 0.8(3)$ & $10.5 \pm 0.5$ & $20.4 \pm 0.2(2)$ & 0 \\
\hline \multicolumn{5}{|l|}{ GC233, on-site } \\
\hline \multicolumn{5}{|l|}{ Vertebrates } \\
\hline Eptatretus sp. ${ }^{\mathrm{a}}$ & -28.6 & 8.2 & & $23-38$ \\
\hline Eptatretus sp. & $-19.8 \pm 1.4(4)$ & $10.3 \pm 1.2(4)$ & $18.4(1)$ & $6-9$ \\
\hline Synaphobranchus sp. & $-42.5(1)$ & $-3.0(1)$ & & $51-85$ \\
\hline Nezumia sp. & $-32.7(1)$ & $2.2(1)$ & & $31-52$ \\
\hline Myctophid & $-18.5 \pm 0.3(3)$ & $7.8 \pm 1.5(3)$ & & 0 \\
\hline Small shark & $-17.8 \pm 0.5(2)$ & $12.7 \pm 0.2(2)$ & $17.8 \pm 0.3(2)$ & 0 \\
\hline \multicolumn{5}{|l|}{ Invertebrates } \\
\hline Bathynomous giganteus & $-19.2 \pm 5.8(6)$ & $12.2 \pm 5.9(6)$ & $18.0 \pm 0.9(3)$ & $0-45$ \\
\hline Rochina crassa & $-23.5 \pm 3.7(2)$ & $7.5 \pm 3.3(2)$ & $13.2 \pm 0.6(2)$ & $18-30$ \\
\hline Buccinum canetae & $-52.6 \pm 1.7(3)$ & $-10.6 \pm 0.9(3)$ & $7.4(1)$ & $71-100$ \\
\hline \multicolumn{5}{|l|}{ GC233, off-site Z-traps } \\
\hline \multicolumn{5}{|l|}{ Invertebrates } \\
\hline Bathynomous giganteus & $-16.4 \pm 1.2(11)$ & $14.1 \pm 1.7(11)$ & $20.1 \pm 1.0(9)$ & 0 \\
\hline Rochina crassa & $-20.9(1)$ & $9.8(1)$ & $12.8(1)$ & $48(\mathrm{~S})$ \\
\hline \multicolumn{5}{|l|}{ GC185, on-site } \\
\hline \multicolumn{5}{|l|}{ Vertebrates } \\
\hline Eptatretus sp. & $-20.9(1)$ & $11.5(1)$ & $12.2(1)$ & $23-55$ \\
\hline Ophicthus cruentifer & $-33.4(1)$ & 7.1 & $-13.3(1)$ & $82-100$ \\
\hline Dysomma rugosa & $-30.4(1)$ & $7.4(1)$ & & $68-100$ \\
\hline \multicolumn{5}{|l|}{ Invertebrates } \\
\hline Bathynomous giganteus & $-17.2 \pm 1.7(2)$ & $15.2 \pm 0.8(2)$ & $17.7 \pm 0.9(2)$ & $5-16(\mathrm{~S})$ \\
\hline Unidentified crab & $-18.4(1)$ & $9.3(1)$ & $19.9(1)$ & 0 \\
\hline Atelecylid crab & $-24.8(1)$ & $9.7(1)$ & & $42-97$ \\
\hline Buccinum canetae & $-29.1 \pm 9.0(2)$ & $6.2 \pm 1.6(2)$ & $-4.5 \pm 6.3(4)$ & $\begin{array}{l}32-100(\mathrm{C}) \\
45-100(\mathrm{~S})\end{array}$ \\
\hline Sclerasterias tanneri & $-33.8 \pm 1.6(3)$ & $5.5 \pm 0.1(3)$ & $3.9(1)$ & $80-100$ \\
\hline \multicolumn{5}{|l|}{ GC185, off-site Z-traps } \\
\hline \multicolumn{5}{|l|}{ Vertebrates } \\
\hline Eptatretus sp. & $-19.8 \pm 2.1(21)$ & $10.6 \pm 1.5(21)$ & $18.7 \pm 2.7(21)$ & $16-40$ \\
\hline \multicolumn{5}{|l|}{ Invertebrates } \\
\hline Bathynomous giganteus & $-15.7 \pm 0.1(8)$ & $14.0 \pm 1.1(8)$ & $18.2 \pm 1.6(10)$ & $6-11(\mathrm{~S})$ \\
\hline Rochina crassa & $-18.6 \pm 1.7(12)$ & $10.4 \pm 1.0(13)$ & $15.6 \pm 1.7(9)$ & $8-17$ \\
\hline Chaceon sp. & $-15.0(1)$ & $9.3(1)$ & $19.7(1)$ & 0 \\
\hline
\end{tabular}



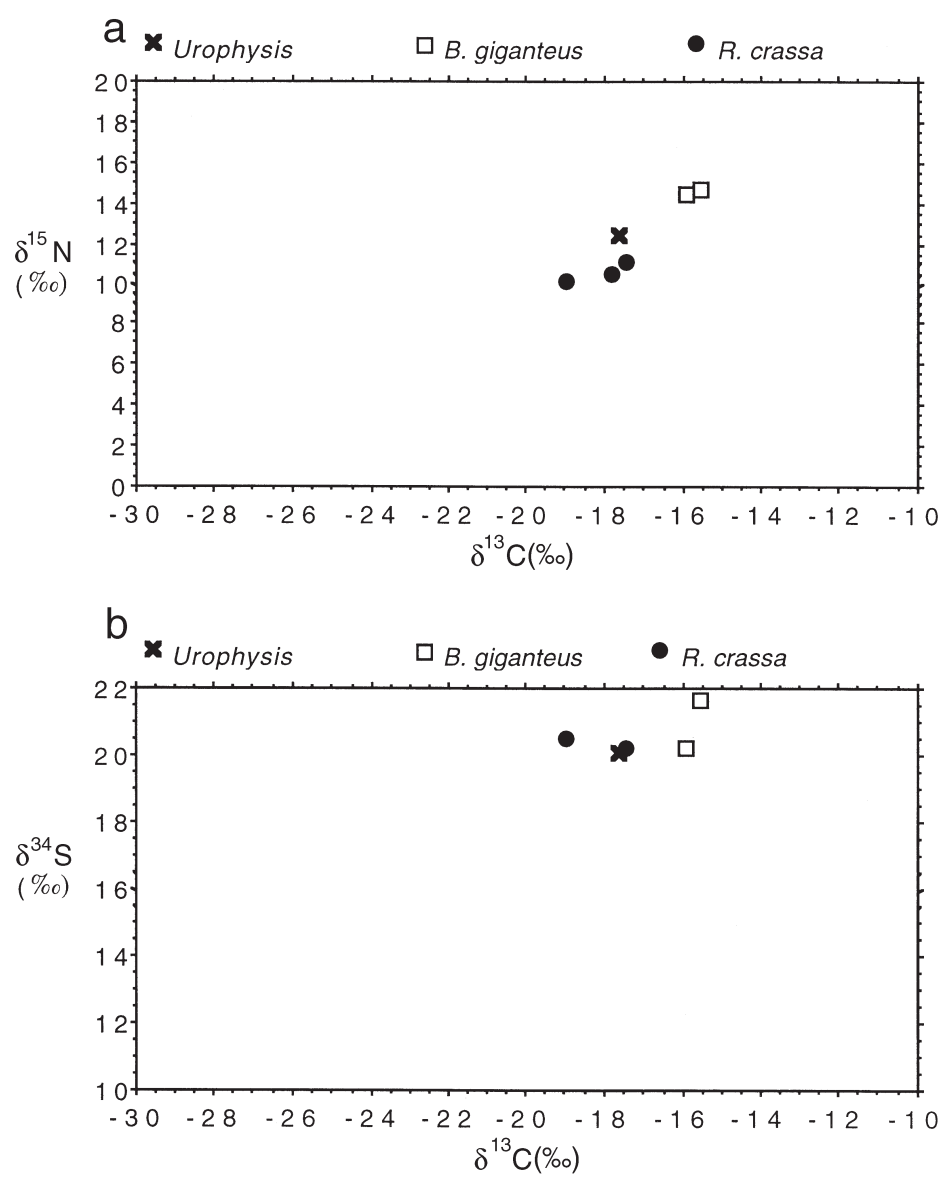

Fig. 3. (a) $\delta^{13} \mathrm{C}$ vs $\delta^{15} \mathrm{~N}$ and (b) $\delta^{13} \mathrm{C}$ vs $\delta^{34} \mathrm{~S}$ for predators collected in Z-traps off GC 234. Urophysis sp. is a hake, Bathynomus giganteus a giant isopod, and Rochina crassa a spider crab

On-site traps at GC 185 caught Bathynomus giganteus (2 specimens) and Eptatretus sp. (1 specimen), while sampling from the submersible produced the predatory sea star Sclerasterias cf. tanneri (3 specimens), gastropod Buccinum canetae (2 specimens), and one specimen each of the eels Ophicthus cruentifer and Dysomma rugosa, an unidentified crab, and an Atelecylid crab (Fig. 4).

Bathynomus giganteus specimens were only slightly depleted in ${ }^{13} \mathrm{C}$ and ${ }^{34} \mathrm{~S}$ relative to background fauna, but relative to those caught off-site (Table 2) there was some indication of a small chemosynthetic contribution. Mixing equations for $\delta^{34} \mathrm{~S}$ indicate that between 5 and $16 \%$ of biomass sulfur was derived from chemosynthetic sources. The trophic enrichment of B. giganteus prevented any meaningful analysis of $\delta^{13} \mathrm{C}$ in mixing equations. The single Eptatretus showed a greater degree of chemosynthetic carbon incorporation (23 to $55 \%$ : Table 2).
Among the other on-site predators captured, most had depleted $\delta^{13} \mathrm{C}$ values, showing clear dependence upon chemosynthetic material. Solution of the mixing equation for $\delta^{13} \mathrm{C}$ showed the eels, gastropod, sea stars, and atelecylid crab to be up to $100 \%$ reliant on seepcommunity carbon. In the case of Buccinum canetae, $\delta^{34} \mathrm{~S}$ values (ranging from -9.6 to $3.8 \%, \mathrm{n}=4$ ) produced a more focused view of consumption. Based on a mixing equation for $\delta^{34} \mathrm{~S}$, a minimum of $80 \%$ of the $B$. canetae biomass sulfur was obtained from chemosynthetic production. The most ${ }^{34} \mathrm{~S}$-enriched of the $B$. canetae, however, was also the most ${ }^{13} \mathrm{C}$-depleted, indicating methanotrophic contributions over thiotrophic sources.

The off-site trapping produced numerous specimens of Eptatretus (21 specimens), Rochina crassa (12 specimens), and Bathynomus giganteus (8 specimens) (Fig. 5). The relatively large sample sizes for the 3 species allowed a more thorough analysis of the data. For Eptatretus the mean off-site GC $185 \delta^{13} \mathrm{C}$ was equal to that on-site at GC 233 (see following subsection), consistent with some incorporation of chemosynthetic organic matter (Table 2). In most cases, the $\delta^{34} \mathrm{~S}$ values of off-site Eptatretus were much too enriched for thiotrophic material to be an important part of its diet (Table 2). There were 3 exceptions, where the hagfish had $\delta^{13} \mathrm{C}$ values of $\leq 20 \%$ and depleted $\delta^{34} \mathrm{~S}$ values $(11.4,12.4$ and $15.4 \%$ ) relative to ocean sulfate. From

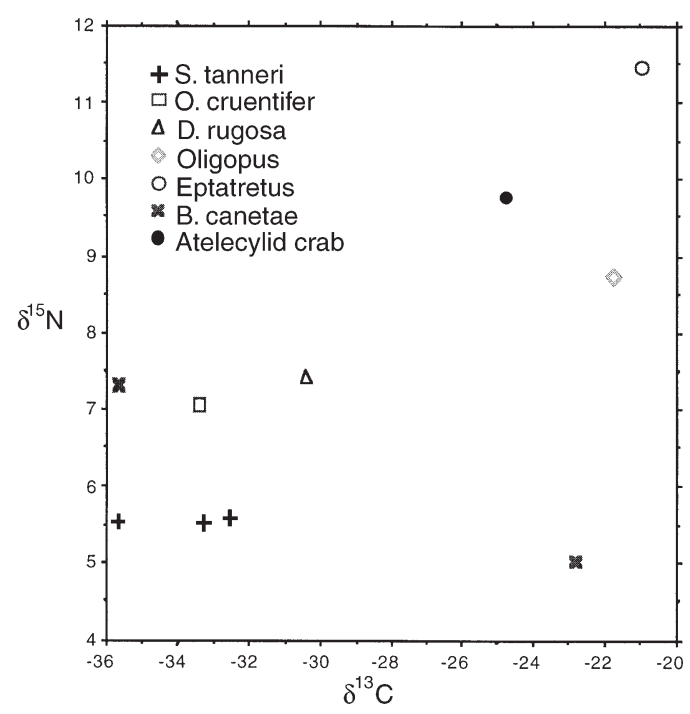

Fig. 4. $\delta^{13} \mathrm{C}$ vs $\delta^{15} \mathrm{~N}$ for predators collected on-site at GC 185. Note that, although the ${ }^{13} \mathrm{C}$-enriched Buccinum canetae was close to values expected for photosynthetic production, its $\delta^{34} \mathrm{~S}$ value was very depleted $(-9.4 \mathrm{ppt})$ relative to ocean sulfate (19 to $20 \%$ ). Sclerasterias tanneri is a sea star, Ophicthus cruentifer and Dysomma rugosa are eels, Oligopus sp. a brotulid fish, Eptatretus sp. a hagfish and Buccinum canetae sp. a predatory snail 
the mixing equation based on $\delta^{34} \mathrm{~S}$ it was estimated that these 3 hagfish derived between 21 to 41,18 to 35 , and 9 to $18 \%$ of their biomass sulfur from tube worms or thiotrophically-derived material similar to tube worms. As mentioned above, the remaining Eptatretus were enriched in ${ }^{34} \mathrm{~S}$, generally near the $20 \%$ value of ocean sulfate. Their $\delta^{13} \mathrm{C}$ values were slightly depleted relative to typical ocean predators, suggesting limited incorporation of chemosynthetic material that was more probably of methanotrophic than thiotrophic origin.

Rochina crassa captured off-site were also depleted in ${ }^{13} \mathrm{C}$ and ${ }^{34} \mathrm{~S}$ relative to background ocean isotopic values. Their $\delta^{13} \mathrm{C}$ and $\delta^{15} \mathrm{~N}$ values overlapped the range observed for the Eptatretus (Fig. 5), but their $\delta^{34} \mathrm{~S}$ was significantly depleted relative to Eptatretus $(\mathrm{p}=0.002)$. The relatively low $\delta^{34} \mathrm{~S}$ combined with $\delta^{13} \mathrm{C}$ values, seldom below $-22 \%$, suggests that tube worm material or organisms that feed on tube worms contribute to the diet of the $R$. crassa. The fact that the $R$. crassa are approximately $8 \%$ higher in $\delta^{15} \mathrm{~N}$ than tube worms, strongly suggests that they did not directly graze upon tube worms but consumed tube worm predators. The mixing equation based on $\delta^{34} \mathrm{~S}$ estimated that the mean percentage of $R$. crassa biomass sulfur derived from thiotrophic sources was 8 to $17 \%$ (Table 2).

Bathynomus giganteus captured off-site were among the most ${ }^{13} \mathrm{C}$-enriched of any animal captured in this study (mean: $16.0 \pm 1.1 \%$ ), however their $\delta^{34} \mathrm{~S}$ values were slightly depleted $(17.9 \%)$ relative to values expected for Gulf of Mexico predators. Using the same end-member $\delta^{34} \mathrm{~S}$ values as with the Rochina crassa above, it is estimated that between 6 and $11 \%$ of the $B$. giganteus biomass sulfur was derived from chemosynthetic production.

\section{GC 233}

Site-specific values for the isotopic signature of the seep food sources was developed from a selection of 1 symbiont-hosting and 3 resident heterotrophic species (Table 1). The values obtained were: $57.3 \pm 9.6 \%$ $\delta^{13} \mathrm{C}_{\text {seep }}(\mathrm{n}=9),-12.5 \pm 6.1 \% \delta^{15} \mathrm{~N} \quad(\mathrm{n}=9)$, and $13.3 \pm 3.7 \% \delta^{34} \mathrm{~S}(\mathrm{n}=7)$. These were dramatically different from the values shared between GC 185 and GC 233 for 2 reasons. First, the dominant symbiontcontaining population is a monoculture of the methanotrophic mussel Bathymodiolus childressi. Second, there are very distinct site-specific isotopic signatures for the methane substrate, which is more biogenic (Brooks et al. 1988, Kennicutt et al. 1992, Sassen et al. 1999), with a depleted $\delta^{13} \mathrm{C}$ signature $\left(\delta^{13} \mathrm{C} \leq-60 \%\right)$. The negative and distinctive $\delta^{15} \mathrm{~N}$

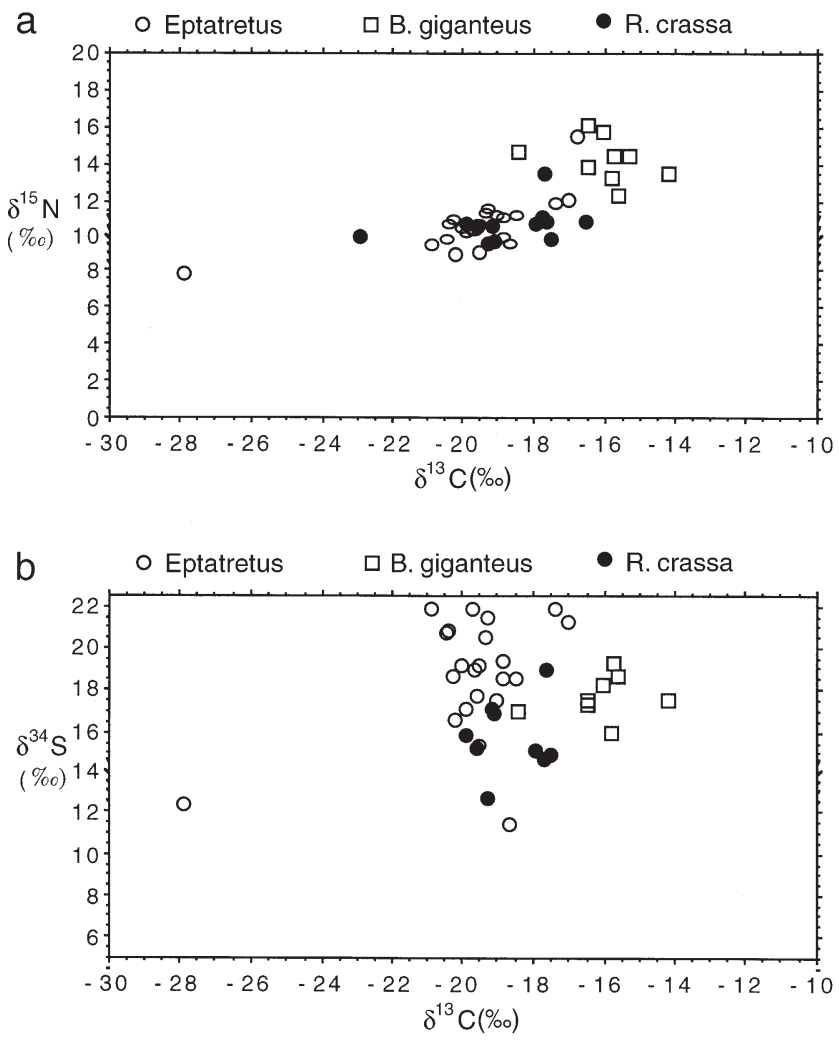

Fig. 5. (a) $\delta^{13} \mathrm{C}$ vs $\delta^{15} \mathrm{~N}$ and (b) $\delta^{13} \mathrm{C}$ vs $\delta^{34} \mathrm{~S}$ for predators caught in Z-traps off GC 185. Eptatretus sp. is a hagfish, Bathynomus giganteus a giant isopod, and Rochina crassa a spider crab

values (Table 2) are probably due to high concentrations of ammonium. Because the greatly depleted nitrogen signal is clearly different from that associated with Gulf of Mexico photosynthesis products (Fry 1983, Macko et al. 1984), $\delta^{15} \mathrm{~N}$ was used in the solution of the mixing equation.

On-site trapping at GC 233 caught the three most common vagrants, Bathynomus giganteus $(6$ specimens), Eptatretus sp. (4 specimens), and Rochina crassa (3 specimens), along with the rattail fish $\mathrm{Nezu}$ mia sp. (1 specimen) and gastropod, Buccinum canetae (3 specimens). Direct collection by the submersible produced the eel Synaphobranchus sp. and a small demersal shark, a pelagic myctophid fish, and an additional specimen of Eptatretus (Fig. 6).

The on-site Eptatretus and Bathynomus giganteus values indicated a general reliance on photosynthetic food, but gave indication of a minor trend in depleted $\delta^{13} \mathrm{C}$ values. Among the B. giganteus, there was a $15 \%$ range in $\delta^{13} \mathrm{C}(-30.6$ to $-15.4 \%$, Fig. $6 a)$. Of the 6 specimens captured, 2 had slightly depleted $\delta^{13} \mathrm{C}$ values and 1 had incorporated substantial chemosynthetic 

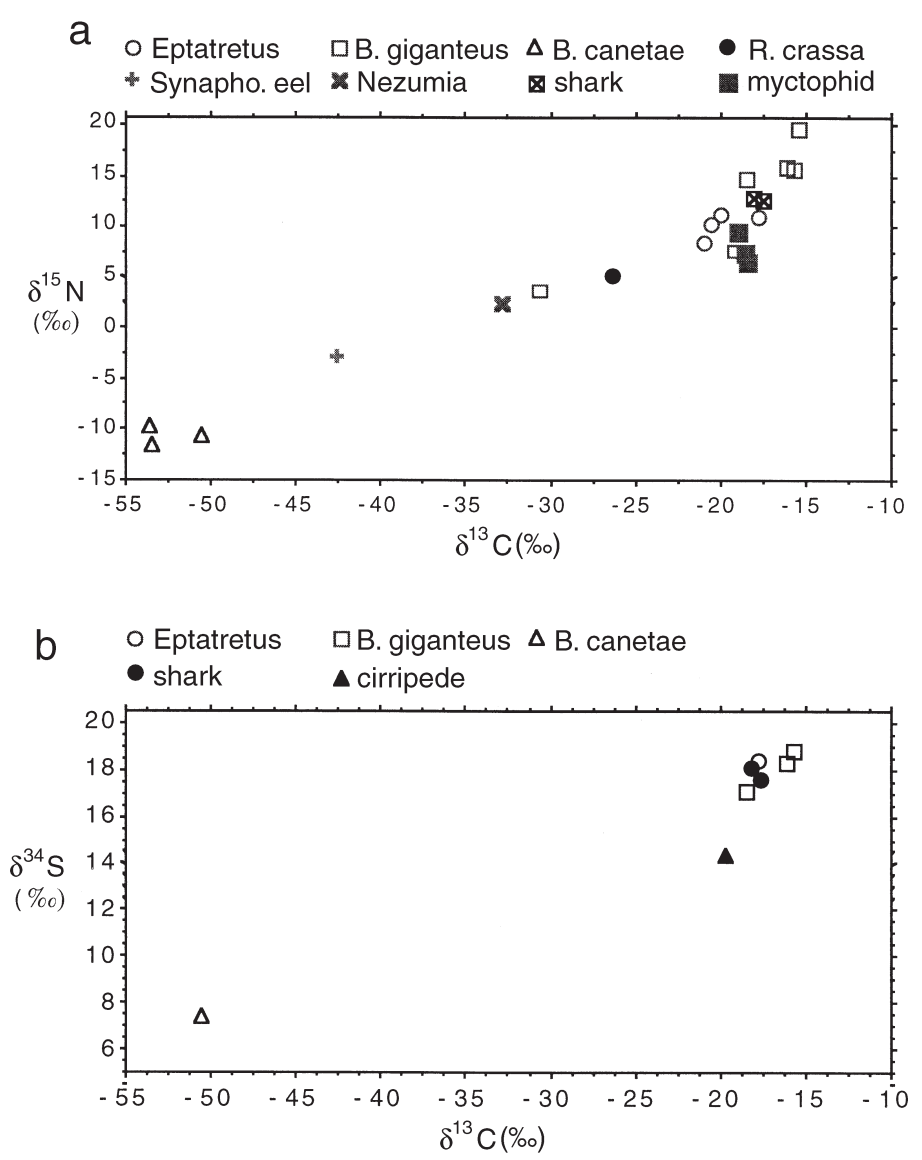

Fig. 6. (a) $\delta^{13} \mathrm{C}$ vs $\delta^{15} \mathrm{~N}$ and (b) $\delta^{13} \mathrm{C}$ vs $\delta^{34} \mathrm{~S}$ for predators collected from small traps deployed at GC 233. Eptatretus sp. is a hagfish, Bathynomus giganteus a giant isopod, Rochina crassa a spider crab, Buccinum canetae a predatory snail, Synaphobranchus sp. an eel, Nezumia sp a rattail fish, and Cirripedia a barnacle taken from the carapace of $R$. crassa

carbon. The most depleted B. giganteus may have incorporated between 27 and $45 \%$ of its carbon from methanotrophic sources, the other 2 moderately depleted B. giganteus incorporated only 3 to $7 \%$ (Table 2). The mean $\delta^{13} \mathrm{C}$ value of Eptatretus from GC 233 was only about $1 \%$ depleted relative to ocean phytoplankton, but significantly depleted relative to the values of those captured at GC 234 ( $p=0.02)$, indicating that the former probably had incorporated a small amount of chemosynthetic carbon. Based on the mixing equation for $\delta^{13} \mathrm{C}$, between 6 and $9 \%$ of the Eptatretus biomass carbon was derived from methanotrophically fixed carbon. The $\delta^{15} \mathrm{~N}$ of the on-site Eptatretus and $B$. giganteus were extremely enriched relative to the 'typical' prey $\delta^{15} \mathrm{~N}$ from GC 233 (Tables 1 $\& 2$ ), however, on-site B. giganteus were depleted in ${ }^{15} \mathrm{~N}$ relative to those captured off-site (see below), indicating small chemosynthetic nitrogen components in their diet. The $3 \mathrm{~B}$. giganteus analyzed for $\delta^{34} \mathrm{~S}$ were the individuals with $\delta^{13} \mathrm{C}$ values similar to open ocean predators. Their enriched $\delta^{34} \mathrm{~S}$ values also indicate their reliance on photosynthetically derived material, although they were not as enriched as $B$. giganteus captured off-site at GC 233 (see below, Figs 6b \& 7b).

Of the other species captured at GC 233, Buccinum canetae, Synaphobranchus, Nezumia, and 1 of 3 Rochina crassa showed greater dependence on chemoautotrophic production. Solving the mixing equation (Eq. 2) for $\delta^{13} \mathrm{C}$ produced results of: R. crassa, 13 to $23 \%$; Nezumia sp., 27 to $47 \%$; B. canetae, 69 to $100 \%$; Synaphobranchus sp., 47 to $83 \%$ (Table 2). Solving the mixing equation for $\delta^{15} \mathrm{~N}$ revealed similar ranges: $R$. crassa, 17 to $30 \%$; Nezumia sp., 26 to $45 \%$; B. canetae, 72 to $100 \%$; Synaphobranchus sp., 46 to $79 \%$.

The off-site trap, deployed approximately $2 \mathrm{~km}$ from the GC $233\left(27^{\circ} 43.86^{\prime} \mathrm{N}, 91^{\circ} 16.48^{\prime} \mathrm{W}\right)$, caught 11 Bathynomus giganteus and 1 Rochina crassa (Fig. 7). The $R$. crassa was distinct, being depleted in ${ }^{13} \mathrm{C}$ relative to typical ocean predators and the same species off-site at GC 234 (Table 2), although not as depleted as the $R$. crassa on-site at GC 233. These values, as well as depleted $\delta^{34} \mathrm{~S}$, were indicative of a consumer utilizing chemosynthetically fixed sulfur. Based on the $\delta^{34} \mathrm{~S}$ values, the $R$. crassa had derived approximately $48 \%$ of its sulfur from methanotrophic material (Table 2). There was no statistical difference in $\delta^{13} \mathrm{C}$ or $\delta^{15} \mathrm{~N}$ between the $B$. giganteus caught on- and off-site at GC 233, however, those caught off-site were significantly more enriched in ${ }^{34} \mathrm{~S}(\mathrm{p}=0.03)$ relative to those on-site, indicating less reliance on seep food sources.

\section{DISCUSSION AND CONCLUSIONS}

Two main conclusions can be drawn from the results reported. First, on a species-specific basis some mobile benthic predators from the background fauna do obtain close to $100 \%$ of their nutrition from seep production, indicating they are residents of the seeps. Vagrant species utilized less than colonists on an individual-by-individual basis. Second, the extent of utilization found in on-site versus off-site trapped vagrant species becomes indistinct as sample size increases, indicating a high degree of movement in and out of the seep habitat for those species.

The mixing equations can be used to estimate that, at these locations, the sea star Sclerasterias cf. tanneri, the gastropod Buccinum canetae, the atelecylid crab, and various fishes (Ophicthus cruentifer, Dysomma rugosa, and Oligopus sp.) generally obtain from 50 to $100 \%$ of their nutrition from seep production. Given the wide isotopic range of seep food sources, these species are probably completely dependent upon the 
seep community for nutrition. The 3 invertebrates have been previously classed as colonists on the basis of high in-seep populations and comparative rarity in the wider background distribution range (Carney 1994). The in-seep versus background abundance of the fishes has yet to be determined, but they seem comparatively rare in the deep fish fauna of the background and may prove to fit within the colonists classification. As such, all these predators represent seep utilization by the background fauna in the sense of becoming part of the seep-site food web during at least part of their life cycle.

The commonly trapped vagrant species are direct exporters of seep production into the background. There was a species-ranking in the degree of utilization consistent with our knowledge of these organisms, Eptatretus sp. consuming the most, followed by Rochina crassa, and Bathynomus giganteus consuming the least. All 3 are opportunists but vary in the versatility of their feeding mechanisms such that their ability to exploit seep production may differ. Eptatretus spp. have not been well studied in the Gulf of Mexico, but the relevant ecology of this hagfish genus has been summarized by Martini (1998). Hagfish of that and other genera are opportunistic predators and scavengers capable of consuming large and small prey, and are widely distributed throughout all except the polar ocean regions, with a known depth range from inshore to $5000 \mathrm{~m}$. As burrowing organisms, their abundance usually goes unnoticed, but they have proven to be one of the most abundant species of demersal fishes at upper slope depths. Eptatretus spp. can be expected to have a wide range of seep prey available to it. $R$. crassa is less well studied, but is a true crab feeding with elongated chelipeds that carry soft tissues to the mouth for ingestion (Williams 1984). Its relatively small chelae are probably not specialized for shellcrushing, limiting seep prey to small thin-shelled juvenile mussels, gastropods and crustaceans or soft-bodied animals. On occasion, specimens were captured which had been feeding upon hydroids, indicating that they can be omnivorous browsers on the limited seep epizoa. B. giganteus appears to have the least adaptable feeding methods and least access to seep prey. Typical of isopods, it lacks specialized food-gathering appendages other than mouthparts. It depends upon small food-handing maxillipeds and powerful, plier-like jaws. The jaws are faced with numerous short spines, making them ideally suited for tearing flesh, but are illsuited for manipulating and crushing shells. In effect, it may have little access to seep biomass and may also be at a competitive dis-advantage with the other 2 vagrant species.
Between colonist and vagrant lies a smaller third group of consumers represented in this study only by 1 Synaphobranchus sp. and the rattail fish Nezumia sp. Both are abundant in the background as with the trapped vagrants, but have seep utilization proportions similar to the background colonists. Both have been directly observed preying on seep crustaceans. In the case of Nezumia there is no obvious indication of a large in-seep population. Synaphobranchus however, burrows, making population assessment difficult. The possibility exists that these species may have restricted foraging areas and are effectively long-term seep residents.

There was an interesting relationship between sample size and the degree of seep utilization that reinforces the role of residency duration. In off-site samples, increased sample size resulted in increased indication of seep feeding. The smallest off-site sample $(\mathrm{n}=9$ at GC 234) indicated little incorporation of seep food. Roughly the same sample size at GC $233(\mathrm{n}=10)$ produced a single specimen of Rochina crassa with a marked seep sulfur signal (Fig. 7). The largest sample
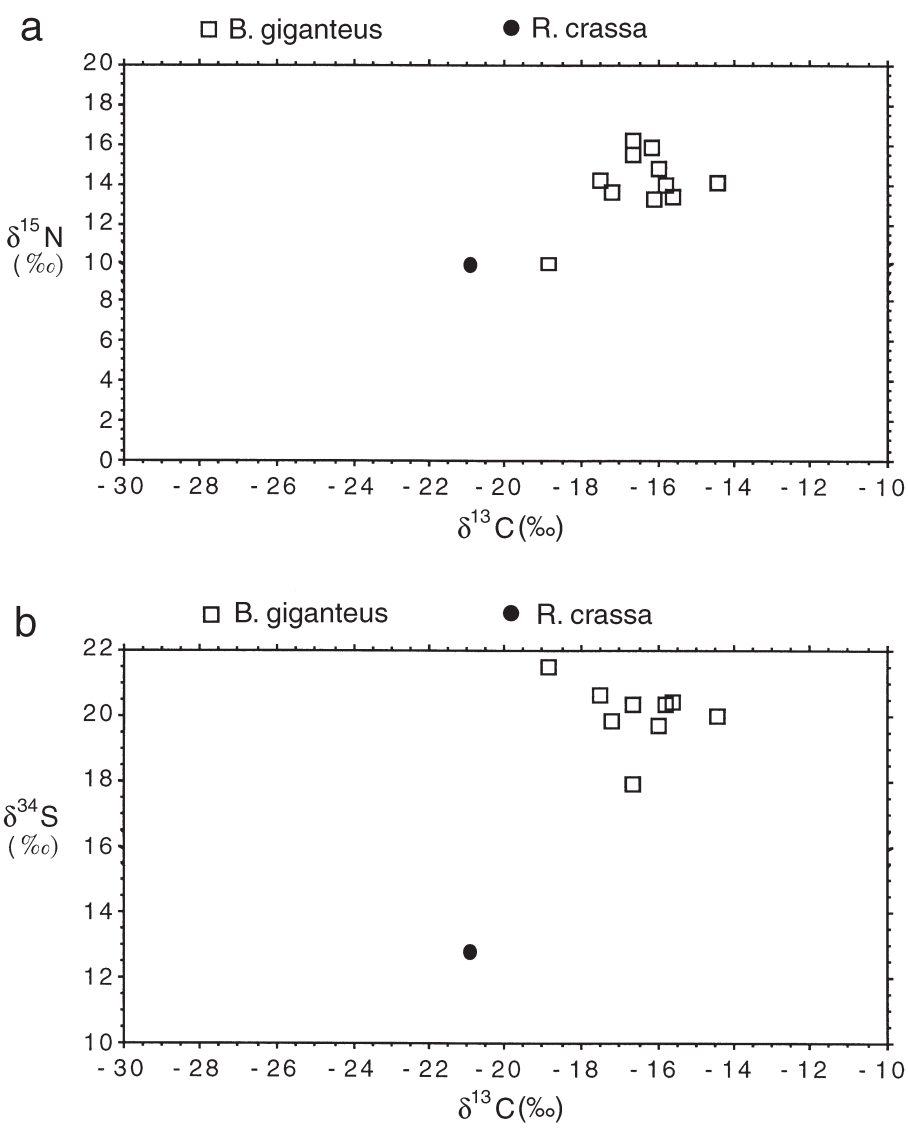

Fig. 7. (a) $\delta^{13} \mathrm{C}$ vs $\delta^{15} \mathrm{~N}$ and (b) $\delta^{13} \mathrm{C}$ vs $\delta^{34} \mathrm{~S}$ for predators collected in Z-traps off GC 233. Bathynomus giganteus is a giant isopod and Rochina crassa a spider crab 
at GC $185(\mathrm{n}=43)$ yielded wide ranges of seep utilization by populations of $R$. crassa and Eptatretus. A trend opposite to that observed off-site is apparent on-site, especially for Eptatretus with increasing sample size, seep utilization became less apparent. Both trends are to be expected if there is considerable movement of individuals between the local areas being sampled by traps. The larger the sample size, the more often a newly arrived animal carrying the trophic label of its previous foraging region will be trapped. At least on the scales employed in this study, vagrants do export seep production.

The continental slope fauna of the Northern Gulf of Mexico have been sufficiently well studied to support the conclusion that background species that have taken up residency, colonists, are rare in the background and constitute a small fraction of the local predatory and scavenging fauna. Similarly, while the known vagrants are relatively common in the background, they comprise a small percent of the total species richness. The overall impression is that a limited number of background species exploit the seep as either long-term or short-term residents. There are 2 main possibilities for this absence of a broader species base of exploitation: (1) a limited availability of seep prey due to biotic defense and predator exclusion from a noxious environment, or (2) an adequate supply of food in the background.

With respect to prey defense, as a result of the sulfide-binding properties of their blood, the tissue of the tube worms normally contains sufficiently high concentrations of $\mathrm{H}_{2} \mathrm{~S}$ to likely render them inedible to most animals (Arp \& Childress 1983), while the shells of the mollusks afford some degree of protection. Tunnicliffe (1992), proposed that noxious exclusion at hydrothermal systems, hydrogen sulfide and brines may produce similar effects at some hydrocarbon seep sites. The fact that so few background species utilize the seep habitat may simply reflect physiological tolerance. Unlike most hydrothermal sites, a diverse suite of background species are often present at seep sites (C. R. Fisher pers. obs.), suggesting that noxious exclusion may not be as extreme as at active vents. Both possibilities can be explored through field experimentation.

Our original expectation that many deep-sea background species would prey upon seep organisms was based upon the generally-held view that food is especially scarce in the deep sea. This may be true in benthic systems at more than $3000 \mathrm{~m}$ under oligotrophic waters, but its application to the upper continental slope must be questioned. The hydrocarbon seeps in this study are in fairly shallow water (500 to $650 \mathrm{~m}$ ). Both the empirical Betzer-Suess relationship (Betzer et al. 1983) for particle flux and the Rowe (1983) relation- ship for benthic biomass indicate that the influx of photo synthetic detritus at these depths is more comparable to that of the continental shelf rather than the abyssal. Reinforcing the possibility of relatively high background food levels is the fact that the upper slope of the Gulf of Mexico supports high populations of large predatory fishes and crabs. This is a common pattern on all upper slopes that is unrelated to the presence or absence to chemosynthetic communities (Gage \& Tyler 1996 and references therein). Ultimately, the role of background food limitation in driving exploitation of seep and vent systems will require comparative studies of trophic patterns among endemic, colonist, and vagrant species in regions of contrasting labile detritus influx. The lower the food resources of the background, the greater the expected level of exploitation should be.

While the results of this study presently lack the standing stock and transfer rates needed to fully quantify trophic export from seeps, it is informative to consider the possibilities. The initial isotope survey of background fauna by Kennicutt \& Brooks (unpubl.) indicated that up to $17 \%$ of the overall benthic fauna in the seep region might have consumed minor amounts of food from seeps. The inability of a single isotope to separate seep carbon from isotopically similar sedimentary organic carbon probably makes this estimate too high, since depleted $\delta^{13} \mathrm{C}$ values were only attributed to seep production. If, however, abundant forms such as the vagrants trapped in the present study have only 1 to $2 \%$ seep carbon in their overall population, then there must be a large export which must exert considerable influence upon the prey populations of the seep community. As to the populations of abundant background consumers, seep food may be so greatly exceeded by phytodetritus-based food at this depth that the overall impact of seep exploitation is minimal. Quite the contrary would be the case for the rarer background species which have colonized the seeps. The well-fed sub-populations resident within the seeps may make a higher reproductive contribution to the overall population than the sparse background subpopulation. In such cases, overall regional persistence of the species may ultimately be dependent upon seep utilization.

Most large mobile predators captured on-site from the 3 chemosynthetic communities showed significant incorporation of chemosynthetic material. This was particularly apparent among predatory snails (Buccinum canetae) and eel-like forms (including Oligopus sp., Synaphobranchus, Ophicthus cruentifer, Eptatretus, Nezumia and Dysomma rugosa). Bathynomus giganteus captured within the seep communities generally showed the least chemosynthetic incorporation, although some individuals incorporated a significant 
amount. Off-site Rochina crassa and Eptatretus (from traps deployed in the vicinity of GC 185 and GC 233) displayed a significant chemosynthetic isotope signal. It is estimated that they may derive $20 \%$ or more of their biomass carbon and sulfur from chemosynthetic sources. B. giganteus captured off-site generally showed little evidence of chemosynthetic usage. These results indicate that chemosynthetic production is exported to Gulf of Mexico predators. Although most mobile benthic predators not physically associated with the chemosynthetic communities derive most of their nutritional needs from photosynthetic production, their incorporation of chemosynthetic production is nevertheless substantial.

Acknowledgements. This work was supported in part by subcontract L100094, S700033 and S70027 to the Mineral Management Service project RF-6899 and the Mineral Management Service, Gulf of Mexico Regional OCS office through contract \#1435-01-96-CT 30813. We would like to thank Dr Ian MacDonald of the Geochemical and Environmental Research Group, Texas A\&M University, and Dr Robert Avent of the Mineral Management Service for their interest and support. This research could not have been accomplished with out the crews of the RV 'Edwin Link' and 'Johnson Sea Link' (Harbor Branch Oceanographic, Fort Pierce, FL). Special thanks to the Pennsylvania State University scientists for their help on board ship: Dirk Berquest, John K. Freytag, Stephane Hordez and Erin McMullen. Credit for species identification goes to: Mary Rice, Smith Marine Station; Tim Shank, Woods Hole Oceanographic; Julie Amber, Millersville University; Brett Begley, Pennsylvania State University; Stephane Hourdez, Equipe Ecophysiologie Station Biologique de Roscoff; Erin McMullen, Pennsylvania State University; Rachel Kosoff, Pennsylvania State University. The suggestions of 4 anonymous referees helped improve this manuscript.

\section{LITERATURE CITED}

Arp AJ, Childress JJ (1983) Sulfide binding by the blood of the hydrothermal vent tube worm Riftia pachyptila. Science 219:295-297

Betzer PR, Showers WL, Laws EA, Winn CD, DiTullio GR, Kroopnick PM (1983) Primary productivity and particle flux on a transect of the equator at $153^{\circ} \mathrm{W}$ in the Pacific Ocean. Deep Sea Res 31:1-11

Brooks JM, Kennicutt MC II, Fisher CR, Macko SA, Cole K, Childress JJ, Bidigare RR, Vetter RD (1987) Deep-sea hydrocarbon seep communities: evidence for energy and nutritional carbon sources. Science 238:1138-1142

Brooks JM, Powell EN, Kennicutt MC II, Carney RS, Rossman I, MacDonald SJ, Bidigare RR, Wade TL (1988) Gulf of Mexico hydrocarbon seep ecosystem studies. NOAA Symp Ser Undersea Res 6:119-135

Carney RC (1994) Consideration of the oasis analogy for chemosynthetic communities at Gulf of Mexico hydrocarbon vents. Geo-Mar Lett 14:149-159

Childress JJ, Fisher CR, Brooks JM, Kennicutt MC, Bidigare $\mathrm{R}$, Anderson A (1986) A methanotrophic marine molluscan symbiosis: mussels fueled by gas. Science 233:1306-1308
Fisher CR (1996) Ecophysiology of primary production at deep-sea vents and seeps. Biosyst Ecol Ser 11:313-336

Fisher CR, Brooks JM, Vodenichar JS, Zande JM, Childressi JJ, Burke RA Jr (1993) The co-occurrence of methanotrophic and chemoautotrophic sulfur-oxidizing bacterial symbionts in a deep-sea mussel. Mar Ecol 14:277-289

Fry B (1983) Fish and shrimp migrations in the northern Gulf of Mexico analyzed using stable $\mathrm{C}, \mathrm{N}$, and $\mathrm{S}$ isotope ratios. Fish Bull (Wash DC) 81:789-801

Fry B, Sherr EB (1984) $\delta^{13} \mathrm{C}$ measurements as indicators of carbon flow in marine and freshwater ecosystems. Contrib Mar Sci 27:13-47

Fry B, Brandt W, Mersch FJ, Tholke K, Garritt R (1992) Automated analysis system for coupled $\delta^{13} \mathrm{C}$ and $\delta^{15} \mathrm{~N}$ measurements. Anal Chem 64:288-291

Gage JD, Tyler PA (1996) Deep-sea biology: a natural history of organisms at the deep-sea floor. 3rd edn. Cambridge University Press, Cambridge, UK

Giesemann A, Jager HJ, Norman AL, Krouse HR, Brand WA (1994) On-line sulfur isotope determination using an elemental analyzer coupled to a mass spectrometer. Anal Chem 66:p2816

Hesslein RH, Capel MJ, Fox DE, Hallard KA (1991) Stable isotopes of sulfur, carbon, and nitrogen as indicators of trophic level and fish migration in the lower Mackenzie River, Canada. Can J Fish Aquat Sci 48:2258-2265

Jumars PA, Mayer LM, Deming JW, Baross JA, Wheatcroft RA (1990) Deep-sea deposit feeding strategies suggested by environmental and feeding constraints. Phil Trans $\mathrm{R}$ Soc Lond A Math Phys Sci 331:85-101

Kennicutt MC II, Brooks JM, Bidigare RR, Fay RR, Wade TL, McDonald TJ (1985) Vent-type taxa in a hydrocarbon seep region on the Louisiana slope. Nature (Lond) 317:351-353

Kennicutt MC II, Burke RA, MacDonald IR, Brooks JM, Denoux GL, Macko SA (1992) Stable isotope partitioning in seep and vent organisms: chemical and ecological significance. Chem Geol 101:293-310

Lajtha K, Michener RH (1994) Stable isotopes in ecology and environmental science. Blackwell Scientific Publications, Cambridge, MA

Lee ET (1992) Statistical methods for survival data analysis. Wadsworth, Belmont, CA

MacAvoy SE, Macko SA, Garman GC (1998) Tracing marine biomass into tidal freshwater ecosystems using stable sulfur isotopes. Naturwissenschaften 85:544-546

MacDonald IR, Boland GS, Baker JS, Brooks JM, Kennicutt MC II, Bidigare RR (1989) Gulf of Mexico hydrocarbon seep communities. Mar Biol 101:235-247

MacDonald IR, Reilly JF, Guinasso NL, Brooks JM, Carney RS, Bryant WA, Bright TJ (1990) Chemosynthetic mussels at a brine-filled pockmark in the northern Gulf of Mexico. Science 248:1096-1099

Macko SA, Entzeroth L, Parker PL (1984) Regional differences in nitrogen and carbon isotopes on the continental shelf of the Gulf of Mexico. Naturwissenschaften 71: 374-375

Maldonado M, Young CM (1998) A new species of poecilosclerid sponge (Porifera) from bathyal methane seeps in the Gulf of Mexico. J Mar Biol Assoc UK 78:795-806

Martini FH (1998) Ecology of hagfishes. Chapter 5. In: Jørgensen JM, Lamholt JP, Weber RE, Malte H (eds) The biology of hagfish. Chapman Hall, London, p 57-77

Michener RH, Schell DM (1994) Stable isotope ratios as tracers in marine aquatic food webs. In: Lajtha K, Michener RH (eds) Stable isotopes in ecology and environmental Science. Blackwell Scientific Publications, Oxford, p 138-157 
Nix ER, Fisher CR, Vodenichar J, Scott KM (1995) Physiological ecology of a mussel with methanotrophic endosymbionts at three hydrocarbon seep sites in the Gulf of Mexico. Mar Biol 122:605-617

Pequegnat WE (1970) Deep-water brachcyuran crabs. Chapter 6. In: Pequegnat WE, Chace FA Jr (eds) Contributions on the biology of the Gulf of Mexico. Gulf Publishing Co., Houston, p 171-204

Pequegnat WE, Gallaway BJ, Pequegnat LH (1990) Aspects of the ecology of the deep-water fauna of the Gulf of Mexico. Am Zool 30:45-64

Peterson BJ, Howarth RW (1987) Sulfur, carbon, and nitrogen isotopes used to trace organic matter flow in the saltmarsh estuaries of Sapelo Island, Georgia. Limnol Oceanogr 32:1195-1213

Rau GH, Hedges JI (1979) Carbon-13 depletion in a hydrothermal vent mussel: suggestion of a chemosynthetic food source. Science 203:648-649

Reilly JF Jr, MacDonald IR, Biegert EK, Brooks JM (1996) Geological controls on the distribution of chemosynthetic communities in the Gulf of Mexico. AAPG (Am Assoc Pet Geol) Mem 66:39-62

Roberts HH, Carney RS (1997) Evidence of episodic fluid, gas, and sediment venting on the Northern Gulf of Mexico continental slope. Econ Geol 92:863-879

Roelke LA, Cifuentes LA (1997) Use of stable isotopes to assess groups of king mackerel, Scomberomorus cavalla,

Editorial responsibility: Otto Kinne (Editor),

Oldendorf/Luhe, Germany in the Gulf of Mexico and southeastern Florida. Fish Bull 95:540-551

Rosner B (1990) Fundamentals of biostatistics, 3rd edn. PWSKent Publishing Company, Boston, MA

Rowe GT (1983) Biomass and production of the deep-sea macrobenthos. In Rowe GT (ed.) The sea, Vol 8. WileyInterscience, New York, p 97-121

Sassen R, Joye S, Sweet ST, DeFreitas DA, Milkov AV, MacDonald IR (1999) Thermogenic gas hydrates and hydrocarbon gases in complex chemosynthetic communities, Gulf of Mexico continental slope. Org Geochem 30:485-497

Smith EB, Scott KM, Nix ER, Korte C, Fisher CR (2001) Growth and condition of seep mussels at a Gulf of Mexico brine pool. Ecology (in press)

Tunnicliffe V (1992) The nature and origin of the modern hydrothermal vent fauna. Palaios 7:338-350

Tunnicliffe V, Jensen RG (1987) Distribution and behavior of the spider crab Macroregonia machrochira Sakai (Brachyura) around hydrothermal vents in the northeast Pacific. Can J Zool 65:2443-2449

Urcuyo IA, Massoth G, Julian D, Fisher CR (2001) A vestimentiferan tube worm aggregation: environment, morphology, growth, biomass and physiological condition. Limnol Oceanogr (in press)

Williams AB (1984) Shrimps, lobsters, and crabs of the Atlantic coast of the eastern US, Maine to Florida. Smithsonian Institution Press, Washington, DC

Submitted: July 7, 2000; Accepted: January 3, 2001

Proofs received from author(s): January 7, 2002 